\title{
In Vitro Enzyme Inhibition Potentials and Antioxidant Activity of Synthetic Flavone Derivatives
}

\author{
Mohammad Shoaib, ${ }^{1}$ Syed Wadood Ali Shah, ${ }^{1}$ Niaz Ali, ${ }^{2}$ \\ Ismail Shah, ${ }^{1}$ Muhammad Naveed Umar, ${ }^{3}$ Shafiullah, ${ }^{1}$ Muhammad Ayaz, \\ Muhammad Nawaz Tahir, ${ }^{4}$ and Sohail Akhtar ${ }^{5}$ \\ ${ }^{1}$ Department of Pharmacy, University of Malakand, Chakdara, Dir Lower, Khyber Pakhtunkhwa 18550, Pakistan \\ ${ }^{2}$ Department of Pharmacology, Institute of Basic Medical Sciences, Khyber Medical University, Peshawar, \\ Khyber Pakhtunkhwa 25000, Pakistan \\ ${ }^{3}$ Department of Chemistry, University of Malakand, Chakdara, Dir Lower, Khyber Pakhtunkhwa 18550, Pakistan \\ ${ }^{4}$ Department of Physics, University of Sargodha, Punjab 40100, Pakistan \\ ${ }^{5}$ Department of Statistics, University of Malakand, Chakdara, Dir Lower, Khyber Pakhtunkhwa 18550, Pakistan
}

Correspondence should be addressed to Syed Wadood Ali Shah; pharmacistsyed@gmail.com

Received 8 March 2015; Accepted 23 April 2015

Academic Editor: Dimitris P. Makris

Copyright (C) 2015 Mohammad Shoaib et al. This is an open access article distributed under the Creative Commons Attribution License, which permits unrestricted use, distribution, and reproduction in any medium, provided the original work is properly cited.

\begin{abstract}
Free radicals are produced by an important chemical process known as oxidation that in turn initiates chain reactions to damage the cells and originate oxidative stress. Flavones have got special position in research field of natural and synthetic organic chemistry due to their biological capabilities as antioxidant. The antioxidants are known to possess extensive biological effects that include antiviral, antibacterial, anti-inflammatory, antithrombotic, and vasodilatory activities. The simple flavone (F1) and substituted flavone derivatives (F2-F5) have been synthesized from $o$-hydroxyacetophenone and benzaldehyde derivatives in good yield. The structures have been established by different spectroscopic techniques like ${ }^{1} \mathrm{H}$ NMR, ${ }^{13} \mathrm{C}$ NMR, IR, and elemental analysis. Antioxidant profile of these compounds was established using DPPH and $\mathrm{H}_{2} \mathrm{O}_{2}$ free radical scavenging assay. The findings showed that halogenated flavones showed more enzyme inhibitions and antioxidant activities than simple flavones and are potential candidates for the treatment of wide range of diseases.
\end{abstract}

\section{Introduction}

Reactive oxygen species (ROS) and the free radicals like superoxide, hydroxyl, alkoxyl, hydroperoxyl, and peroxyl are produced during normal metabolism in humans [1]. Free radicals are produced by an important chemical process known as oxidation that in turn initiates chain reactions to damage the cells and originate oxidative stress. This process leads to the development of different disorders like Alzheimer's disease [2, 3], Parkinson's disease [4], the pathologies caused by diabetes $[5,6]$, rheumatoid arthritis [7], and neurodegeneration in motor neuron [8]. The antioxidants have been used specifically as to stop the chain reactions by the removal of free radical intermediates and slow down other oxidation processes by oxidizing themselves and act as reducing agents like polyphenols or ascorbic acid [9]. Naturally, a complex system of enzymes and antioxidant metabolites work in coordination to stop oxidative damage to the cellular components like proteins, DNA, and lipids by preventing the formation or removal of these reactive species before damaging the important components of the cells $[10,11]$.

Lipoxygenases (LOX) are the members of a class of nonheme iron containing dioxygenases that catalyze the first step in the arachidonic acid cascade that lead to formation of lipoxins and leukotrienes involved in the variety of inflammatory responses [12]. Alzheimer's disease is the common reason of mental illness (dementia) that shows a progressive loss of cholinergic synapses in the brain regions. Mostly, a decreased level of neurotransmitter acetylcholine 
$(\mathrm{ACh})$ at neuromuscular junction plays a critical role in this disease. Hence, these types of disorders can be overcome by restoring the adequate level of neurotransmitter to inhibit cholinesterase using agents known as anticholinesterase [13].

In general, the flavonoids are reported to possess potent antioxidant activity [14] by scavenging hydroxyl radicals, superoxide anions, and lipid peroxyradicals $[15,16]$. Based upon the significance of flavonoids, an attempt was made to synthesize the flavones derivatives for their possible enzyme inhibition and antioxidant potentials. Here, the first objective was to report synthesis of flavones derivatives and its evaluation for enzyme inhibition and antioxidant activities. The second objective was to establish the structure activity relationship (SAR) of the flavone derivatives.

\section{Experimental}

2.1. Materials. Ketone and benzaldehyde derivatives, DPPH, ascorbic acid, quercetin, rutin, silica, DTNB 5,5-dithiobisnitrobenzoic acid, enzymes including 15-lipoxigenase (soybean), AChE Electric eel, substrates acetylthiocholine iodide, and galantamine hydrobromide were of Sigma Aldrich Chemical Company. TLC plates were of Merck 60 F254, Darmstadt, Germany. Solvents and chemicals like ethanol, nhexane, ethyl acetate, dipotassium hydrogen phosphate, and potassium dihydrogen phosphate used were of extra pure analytical grade and were purchased from E. Merck.

${ }^{1} \mathrm{H}$-NMR and ${ }^{13} \mathrm{C}$ NMR spectra were recorded in deuterated chloroform ( $\mathrm{CDCl} 3)$ on Bruker SF spectrometers operating at 300 and 75 megahertz $(\mathrm{MHz})$ frequencies, respectively. Chemical shifts values are expressed in $\delta$ (ppm) downfield relative to TMS which was used as an internal standard. Infrared spectra were recorded on Thermo Scientific USA (Nicolet 6700) Infrared spectrometer on KBr disk method. All melting points are uncorrected and were taken in open capillary tubes using Electrothermal 9100 apparatus (Barnstead, UK). Reaction extents and final products purities were checked on TLC plates (Merck 60 F254, Darmstadt, Germany) and spots were visualized under UV Lamp (180$365 \mathrm{~nm}$ ) and with subsequent staining with iodine vapours.

2.2. General Procedure for the Synthesis of Flavone Derivatives (F1, F2, F3, F4, and F5). To an ethanolic solution of 2-hydroxyacetophenone (15 mili mol), sodium hydroxide $(10 \mathrm{~mL}, 40 \%$ ethanolic) was added dropwise at room temperature. Then corresponding benzaldehyde derivatives (15 mili mol) were added dropwise to this mixture and stirred for 24 hours at room temperature $\left(25 \pm 2^{\circ} \mathrm{C}\right)$. The reaction was monitored by TLC and upon completion of the reaction, it was poured into crushed ice and neutralized with $1 \mathrm{~N} \mathrm{HCl}$ solution resulting in yellow precipitates of corresponding chalcones. The chalcones were filtered and washed with water to remove the impurities.

In the next step, the respective chalcones were cyclized to flavone derivatives in $15 \mathrm{~mL}$ DMSO in the presence of iodine (375 mg) at $140^{\circ} \mathrm{C}$ for 1 hour separately. Upon completion of reactions, the mixtures were cooled to room temperature and poured into water followed by extraction with ethyl acetate $(25 \mathrm{~mL} \times 3)$, treated with sodium thiosulfate solution $(20 \%)$

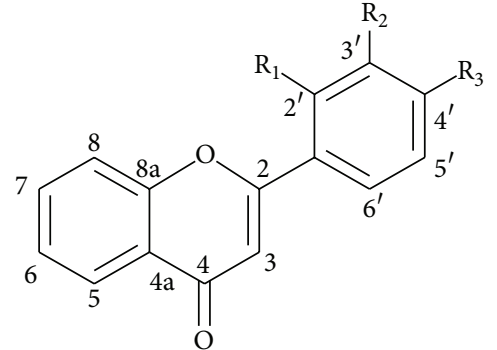

FIGURE 1: Structure of flavone derivatives.

and brine solution, and dried over sodium sulfate. The final products (mixture of flavone and chalcone) were subjected to column chromatography using n-hexane: ethyl acetate $(9: 1)$ to purify flavones derivatives (Figure 1) [17].

2-Phenyl-4H-chromen-4-one (F1). ${ }^{1} \mathrm{H}$ NMR $(300 \mathrm{MHz}$, Chloroform- $d$ ) $\delta 8.22$ (dd, $J=8.0,1.7 \mathrm{~Hz}, 1 \mathrm{H}), 7.75-7.53$ $(\mathrm{m}, 5 \mathrm{H}), 7.50-7.37(\mathrm{~m}, 4 \mathrm{H}), 6.85(\mathrm{~s}, 1 \mathrm{H}) .{ }^{13} \mathrm{C}$ NMR $(75 \mathrm{MHz}$, $\left.\mathrm{CDCl}_{3}\right) \delta 178.48,163.42,156.26,133.79,131.77,131.61,129.04$, $126.66,125.71,125.24,123.95,118.09,107.58 \mathrm{IR}(\mathrm{KBr}), v$, $\mathrm{cm}^{-1}, 1635.4,1463.3,1372.4,766.0$. Found, \%: C 81.07; H 4.54. $\mathrm{C}_{15} \mathrm{H}_{10} \mathrm{O}_{2}$. Calculated, \%: C 81.19; H $4.60[18,19]$.

2-(4-(Dimethylamino)phenyl)-4H-chromen-4-one (F2). ${ }^{1} \mathrm{H}$ NMR (300 MHz, Chloroform-d) $\delta 8.24(\mathrm{dd}, J=7.9,1.7 \mathrm{~Hz}$, $1 \mathrm{H}), 7.89-7.81(\mathrm{~m}, 2 \mathrm{H}), 7.68$ (ddd, $J=8.7,7.1,1.7 \mathrm{~Hz}, 1 \mathrm{H})$, 7.55 (dd, $J=8.4,1.3 \mathrm{~Hz}, 1 \mathrm{H}), 7.40$ (ddd, $J=8.1,7.1,1.1 \mathrm{~Hz}$, $1 \mathrm{H}), 6.80-6.76(\mathrm{~m}, 2 \mathrm{H}), 6.73(\mathrm{~s}, 1 \mathrm{H}), 3.10(\mathrm{~s}, 6 \mathrm{H}) .{ }^{13} \mathrm{C} \mathrm{NMR}$ $(100 \mathrm{MHz}$, Chloroform- $d) \delta \mathrm{ppm}=178.20,163.7,156.50$, $152.60,133.22,127.75,125.58,124.81,124.03,117.84,111.66$, 104.39, 40.10. IR (KBr) $v, \mathrm{~cm}^{-1}, 2919.4(\mathrm{CH}) 1730.3(\mathrm{C}=\mathrm{O})$, 1197.8 and $1363.2(\mathrm{C}-\mathrm{N}), 1558.1(\mathrm{C}=\mathrm{C}), 3311.5(=\mathrm{C}-\mathrm{H}) 1127.2$ (C-O). Found, \%: C 76.96; $\mathrm{H} 5.70 ; \mathrm{N}$ 5.28. $\mathrm{C}_{17} \mathrm{H}_{15} \mathrm{~N}_{\mathrm{O} 2}$. Calculated, \%: C 76.59; H 5.60; N 5.60.

2-(2,4-Dichlorophenyl)-4H-chromen-4-one (F3). ${ }^{1} \mathrm{H}$ NMR $(300 \mathrm{MHz}$, Chloroform- $d) \delta 8.27$ (dd, $J=8.0,1.7 \mathrm{~Hz}, 1 \mathrm{H}, \mathrm{H}-$ $3^{\prime}$ ), 7.74 (ddd, $\left.J=8.7,7.1,1.7 \mathrm{~Hz}, 1 \mathrm{H}, 5^{\prime}-\mathrm{H}\right), 7.64-7.56(\mathrm{~m}, 2 \mathrm{H}$, 5-H, $\left.6^{\prime}-\mathrm{H}\right), 7.55-7.40(\mathrm{~m}, 3 \mathrm{H}, 6-\mathrm{H}, 7-\mathrm{H}, 8-\mathrm{H}), 6.68$ (s, 1H, H3). ${ }^{13} \mathrm{C} \mathrm{NMR}\left(75 \mathrm{MHz}, \mathrm{CDCl}_{3}, \mathrm{ppm}\right) \delta 177.98,161.51,156.54$, $137.43,134.06,133.81,131.42,130.77,130.40,127.58,125.82$, $125.50,123.81,118.18,113.16$. IR $(\mathrm{KBr}) V_{\max } \mathrm{cm}^{-1}: 3066.5$, 2920.6, 1734.1, 1645.4, 1221.1, 748.2. Found, \%: C 60.99; H 2.28. $\mathrm{C}_{15} \mathrm{H}_{8} \mathrm{Cl}_{2} \mathrm{O}_{2}$. Calculated, \%: C 61.88; H 2.77.

2-(2,3-Dichlorophenyl)-4H-chromen-4-one (F4). ${ }^{1} \mathrm{H}$ NMR (300 MHz, Chloroform-d) $\delta 8.32-8.17\left(\mathrm{~m}, 1 \mathrm{H}, \mathrm{H} 4^{\prime}\right), 7.86-$ $7.61\left(\mathrm{~m}, 2 \mathrm{H}, \mathrm{H} 5^{\prime}, 6^{\prime}\right), 7.56-7.21(\mathrm{~m}, 4 \mathrm{H}, \mathrm{H}-5,6,7,8), 6.67$ (s, $1 \mathrm{H}, \mathrm{H} 3) .{ }^{13} \mathrm{C} \mathrm{NMR}\left(75 \mathrm{MHz}, \mathrm{CDCl}_{3}\right) \delta 178.39,162.62,156.58$, $134.60,134.26,134.08,132.62,129.80,128.93,127.65,125.85$, $125.61,123.69,118.23,112.98$. IR $(\mathrm{KBr}) V_{\max } \mathrm{cm}^{-1}: 3048.9$, 2918.5, 1714.7, 1659.3, 1191.3, 747.8. Found, \%: C 62.02; H 2.46. $\mathrm{C}_{15} \mathrm{H}_{8} \mathrm{Cl}_{2} \mathrm{O}_{2}$. Calculated, \%: C 61.88; H 2.77.

2-(3,4-Dichlorophenyl)-4H-chromen-4-one (F5). ${ }^{1} \mathrm{H}$ NMR $(300 \mathrm{MHz}$, Chloroform-d) $\delta 8.24$ (dd, $J=8.0,1.7 \mathrm{~Hz}, 1 \mathrm{H})$, 
$8.04(\mathrm{~d}, J=2.1 \mathrm{~Hz}, 1 \mathrm{H}), 7.74(\mathrm{tq}, J=7.0,2.2 \mathrm{~Hz}, 2 \mathrm{H}), 7.65-$ $7.56(\mathrm{~m}, 2 \mathrm{H}), 7.46(\mathrm{ddd}, J=8.2,7.1,1.1 \mathrm{~Hz}, 1 \mathrm{H}), 6.80(\mathrm{~s}$, 1H). ${ }^{13} \mathrm{C} \mathrm{NMR}\left(75 \mathrm{MHz}, \mathrm{CDCl}_{3}\right) \delta 178.03,160.82,156.08$, $135.96,134.09,133.70,131.69,131.11,128.06,125.78,125.55$, $125.25,123.87,118.06,108.19$. IR (KBr) $v, \mathrm{~cm}^{-1}, 1659.3,1413.7$, $1378.8,750.04,747.8$. Found, \%: C 61.92; $\mathrm{H} 2.53 . \mathrm{C}_{15} \mathrm{H}_{8} \mathrm{Cl}_{2} \mathrm{O}_{2}$. Calculated, \%: C 61.88; H 2.77.

\subsection{In Vitro Antioxidant and Enzyme Inhibition Activity}

2.3.1. DPPH Radical Scavenging Activity. The antioxidant activity of the synthesized compounds, ascorbic acid, tocopherol, and rutin was measured with the slight modifications using DPPH. 2\% methanolic solution of DPPH was freshly prepared and $1 \mathrm{~mL}$ from this solution was added to each $1 \mathrm{~mL}$ of different concentrations of the tested flavone derivatives ranging from 25 to $150 \mu \mathrm{g} / \mathrm{mL}$.

After 30 minutes, the absorbance was measured at $517 \mathrm{~nm}$. Ascorbic acid, tocopherol, and rutin were used as a positive control. The scavenging activity of tested samples was calculated by the following formula in triplicate [20]:

$$
\begin{aligned}
\% \text { scavenging }= & \left\{\frac{(\text { Abs control }- \text { Abs sample })}{(\text { Abs control })}\right\} \\
& \times 100,
\end{aligned}
$$

where $A_{\text {control }}=$ absorbance of $\mathrm{DPPH}+$ methanol and $A_{\text {sample }}=$ absorbance of DPPH + sample/standard.

2.3.2. Hydrogen Peroxide Scavenging Activity. The antioxidant activity of the synthesized compounds, ascorbic acid, tocopherol, and rutin was measured with the slight modifications using hydrogen peroxide. A $2 \mathrm{mM}$ solution of hydrogen peroxide was prepared in phosphate buffer $(50 \mathrm{mM}, \mathrm{pH} 7.4)$. $0.1 \mathrm{~mL}$ of flavone derivatives $(25-150 \mu \mathrm{g} / \mathrm{mL})$ was transferred into test tubes and their volumes were made up to $0.4 \mathrm{~mL}$ with phosphate buffer or solvent. After careful addition of hydrogen peroxide solution $(0.6 \mathrm{~mL})$, tubes were then incubated for 10 minutes and were determined against a blank (50 mM phosphate buffer). Ascorbic acid, tocopherol, and rutin were used as a positive control [20].

The scavenging ability was calculated (in triplicate) by the following formula:

\%scavenging activity

$$
=\left\{\frac{(\text { Abs control }- \text { Abs sample })}{(\text { Abs control })}\right\} \times 100 \text {, }
$$

where $A_{\text {control }}=$ absorbance of $\mathrm{H}_{2} \mathrm{O}_{2}+$ methanol and $A_{\text {sample }}=$ absorbance of $\mathrm{H}_{2} \mathrm{O}_{2}+$ sample/standard.

2.3.3. In Vitro Lipoxygenase Activity. The lipoxygenase activity of synthesized flavones was determined by spectrophotometric method with slight modification. Inhibition was determined by measuring the loss of soybean 15-LOX activity $(5 \mu \mathrm{g})$ with $0.2 \mu \mathrm{M}$ linoleic acid as the substrate prepared in borate buffer $(0.2 \mathrm{M}, \mathrm{pH} 9.0)$. The inhibition in triplicate at various concentrations of synthetic flavones $(12.5,25,50,100$, 150,200 , and $250 \mu \mathrm{g} / \mathrm{mL}$ ) was recorded at $234 \mathrm{~nm}$ using UVVis spectrophotometer. Indomethacin and quercetin were used as positive control, while methanol was used as negative control. $\mathrm{IC}_{50}$ indicating the concentration of $50 \%$ inhibition was also calculated [21].

2.3.4. In Vitro Anticholinesterase Activity. The in vitro anticholinesterase activity of synthesized flavones was determined by spectrophotometric method with slight modification as per our previous reported method. Various concentrations of synthetic flavones further diluted in phosphate buffer $(0.1 \mathrm{M})$ in different concentrations $(12.5,25,50,100$, 150,200 , and $250 \mu \mathrm{g} / \mathrm{mL}$ ) were achieved. AChE (518 U/mg) was diluted in $0.1 \mathrm{M}$ phosphate buffer $(\mathrm{pH} 8.0)$ until final concentration of $0.03 \mathrm{U} / \mathrm{mL}$ (AChE) was obtained. Solutions of DTNB $(0.2273 \mathrm{mM})$ and ATchI $(0.5 \mathrm{mM})$ were prepared in distilled water. For each sample, enzyme solution of $5 \mu \mathrm{L}$ followed by flavones derivatives $(205 \mu \mathrm{L})$ and DTNB reagent ( $5 \mu \mathrm{L}$ ) were mixed. The solution mixture was maintained at $30^{\circ} \mathrm{C}$ for $15 \mathrm{~min}$ using water bath with subsequent addition of substrate solution $(5 \mu \mathrm{L})$. A double beam spectrophotometer (Thermo Electron Corporation, USA) was used to measure the absorbance at $412 \mathrm{~nm}$. $\mathrm{IC}_{50}$ indicating the concentration of $50 \%$ inhibition was also calculated [22].

2.4. Statistical Analysis. Data are presented as mean \pm SEM. Analysis of variance and Dunnett's test are statistically manipulated with GraphPad Prism 5 version 5.01 software.

\section{Results and Discussion}

The general structure and physical parameters of flavone derivatives are given in Figure 1 and Table 1 . The in vitro enzyme inhibition potentials capacity of the flavones derivatives was determined and $\mathrm{IC}_{50}$ values are given in Table 2. It is evident that halogenated derived flavones (F3, F4, and F5) showed good activity in comparison with other flavones derivatives (F1 and F2). These results suggest that change in the position or additional moiety may increase or decrease the potency of individual flavones. The antioxidant capacity of the flavones derivatives was estimated with DPPH and $\mathrm{H}_{2} \mathrm{O}_{2}$ scavenging systems and results are shown in Tables 3 and 4 . The concentration dependent DPPH scavenging effects of flavones derivatives are given. Among the synthesized flavones, the maximum concentration dependent DPPH scavenging effects of $83.16(P<0.001)$ at $120 \mu \mathrm{g} / \mathrm{mL}$ were observed by F5 while mild effects of $51.06(P<0.05)$ were produced by $\mathbf{F} 2$ at ahigh concentration of $120 \mu \mathrm{g} / \mathrm{mL}$ and are comparable with standard ascorbic acid, tocopherol, and rutin. Similar type of findings was observed using $\mathrm{H}_{2} \mathrm{O}_{2}$ scavenging system and is given in Table 4 . It is evident from the results (Table 1) that nitrogen containing flavone derivative (F2) showed less activity in comparison with halogenated one (F5). Other halogens containing flavones (F3 and F4) also showed antioxidant activity but it was less in comparison to $\mathbf{F 5}$, thus suggesting that positioning of halogens may increase or decrease the antioxidant effects as 
TABLE 1: Physical parameters of flavone derivatives.

\begin{tabular}{lccccccc}
\hline Flavone & $\mathrm{R}_{1}$ & $\mathrm{R}_{2}$ & $\mathrm{R}_{3}$ & Yield & Appearance & $R_{f}$ & M.P. $\left({ }^{\circ} \mathrm{C}\right)$ \\
\hline F1 & $-\mathrm{H}$ & $-\mathrm{H}$ & $-\mathrm{H}$ & $68.7 \%$ & Creamy white solid & 0.58 & $96-98$ \\
F2 & $-\mathrm{H}$ & $-\mathrm{H}$ & $-\mathrm{N}\left(\mathrm{CH}_{3}\right)_{2}$ & $73.6 \%$ & Brick red solid & 0.67 & $107-109$ \\
F3 & $-\mathrm{Cl}$ & $-\mathrm{H}$ & $-\mathrm{Cl}$ & $87.0 \%$ & White solid & 0.57 & 90.5 \\
F4 & $-\mathrm{Cl}$ & $-\mathrm{Cl}$ & $-\mathrm{H}$ & $81.0 \%$ & White solid & 0.64 & 88.3 \\
F5 & $-\mathrm{H}$ & $-\mathrm{Cl}$ & $-\mathrm{Cl}$ & $79.3 \%$ & White solid & 0.61 & $195-197$ \\
\hline
\end{tabular}

TABLE 2: In vitro enzyme inhibition potentials of flavone derivatives.

\begin{tabular}{lcc}
\hline Sample test & LOX & AChE \\
& $\mathrm{IC}_{50}(\mu \mathrm{g} / \mathrm{mL})$ & $\mathrm{IC}_{50}(\mu \mathrm{g} / \mathrm{mL})$ \\
\hline F1 & $77.29 \pm 1.32$ & $187.23 \pm 1.65$ \\
F2 & $98.63 \pm 1.91$ & $\geq 250$ \\
F3 & $65.75 \pm 1.45$ & $131.33 \pm 1.05$ \\
F4 & $61.62 \pm 1.15$ & $126.29 \pm 1.39$ \\
F5 & $58.33 \pm 1.69$ & $112.33 \pm 1.68$ \\
Indomethacin & $53.66 \pm 1.38$ & - \\
Quercetin & $38.50 \pm 1.72$ & - \\
Galantamine & - & $25.66 \pm 1.09$ \\
\hline
\end{tabular}

All the values were expressed as mean $\pm \operatorname{SEM}(n=3)$.

evident from the findings. Simple flavone (F1) also produced the effects that were almost similar to halogenated ones. These findings may help the future research and open a new window for the synthesis of potent antioxidants for the treatment of wide range of diseases associated with ROS.

In normal situations, the free radicals as by-products are constantly formed by the body's cells from the cellular redox process using oxygen, an essential element of life [23]. These are generally called reactive oxygen species (ROS) and have a special attraction for proteins, carbohydrates, lipids, and nucleic acids [24]. It has been reported that ROS can be both beneficial and harmful based on the concentration and environment in the biological systems $[25,26]$. The beneficial effects involve a defense against infections, function of cellular signaling, and gene expression. On the other hand, the ROS can mediate injury to cell structures and often referred to as an "oxidative stress" [27]. The harmful effects of ROS are counteracted by antioxidants, some of which are enzymes present in the body [28].

Natural antioxidants like $\alpha$-tocopherol, carotenoids, ascorbic acid, flavonoids, and other phenolic compounds might also play a significant role as physiological and dietary antioxidants $[29,30]$. The natural antioxidants are known to possess extensive biological effects that include anticancer, antiviral, antibacterial, anti-inflammatory, antithrombotic, and vasodilatory activities [31].

One method of estimating the antioxidant activity is based on the use of a stable free radical known as DPPH [32-35] and the electron donation ability of antioxidants can be determined by DPPH purple-colored solution bleaching [36]. This method is based on scavenging of DPPH through the addition of an antioxidant that decolorizes the DPPH solution and degree of decolorization is proportional to the free radical scavenging activity indicating its potency [37]. Hydrogen peroxide occurs naturally at low concentration in the air, water, food, plants, microorganisms, and human body [38]. $\mathrm{H}_{2} \mathrm{O}_{2}$ rapidly converts into water and oxygen and may produce hydroxyl radicals $\left({ }^{\circ} \mathrm{OH}\right)$ that can initiate the lipid peroxidation and cause damage to DNA [39].

LOXs are sensitive to antioxidants as they are involved in inhibition of lipid hydroperoxide formation due to scavenging of lipid oxy- or peroxyradicals and can minimize LOX catalysis by less availability of lipid hydroperoxide substrate [40]. Studies have implicated oxygen free radicals in the process of inflammation and phenolic compounds like flavonoids may block the cascade process of arachidonic acid metabolism by inhibiting lipoxygenase activity and may serve as a scavenger of reactive free radicals which are produced during arachidonic acid metabolism [41].

Flavonoids are phenolic compounds that are mostly present in fruits, vegetables, and tea; they are an integral part of the human diet [42]. Synthetic as well as naturally occurring flavonoid derivatives have many interesting pharmacological activities. These include antitumor $[43,44]$, anticonvulsant [45], vasorelaxant [46], analgesic [47], antioxidant [48], and anti-inflammatory [49] activities. Various synthetic halogenated flavonoids derivatives have been found to be very potent natural flavonoids [50, 51].

Several studies have reported that natural antioxidants are associated with low rate of heart, cancer, diabetes, and other diseases associated with ageing $[52,53]$. These findings will help the researcher to explore the development of synthetic flavones derivatives for the treatment of wide range of diseases associated with ROS like inflammation and Alzheimer's disease.

\section{Conclusion}

In conclusion, the present study confirms the enzyme inhibition and antioxidant activities of flavone derivatives. These findings will open a new channel to synthesize halogenated flavones and explore the development of synthetic flavones derivatives for the treatment of wide range of diseases associated with ROS.

\section{Conflict of Interests}

The authors declare that there is no conflict of interests regarding the publication of this paper. 
TABLE 3: DPPH radical scavenging activity of flavone derivatives.

\begin{tabular}{|c|c|c|c|c|c|c|}
\hline & \multicolumn{6}{|c|}{ \% Scavenging activity (DPPH) } \\
\hline & $25 \mu \mathrm{g} / \mathrm{mL}$ & $50 \mu \mathrm{g} / \mathrm{mL}$ & $75 \mu \mathrm{g} / \mathrm{mL}$ & $100 \mu \mathrm{g} / \mathrm{mL}$ & $125 \mu \mathrm{g} / \mathrm{mL}$ & $150 \mu \mathrm{g} / \mathrm{mL}$ \\
\hline Ascorbic acid & $65.23 \pm 0.41$ & $71.56 \pm 0.61$ & $75.26 \pm 0.68$ & $81.09 \pm 0.42$ & $86.11 \pm 0.87$ & $90.68 \pm 0.58$ \\
\hline Tocopherol & $72.32 \pm 0.36$ & $79.16 \pm 0.57$ & $84.41 \pm 0.61$ & $90.18 \pm 0.53$ & $92.24 \pm 0.75$ & $94.33 \pm 0.49$ \\
\hline Rutin & $79.03 \pm 0.76$ & $83.11 \pm 0.43$ & $87.63 \pm 0.81$ & $91.25 \pm 0.61$ & $95.35 \pm 0.66$ & $97.67 \pm 0.51$ \\
\hline $\mathrm{F} 1$ & $32.12 \pm 0.61$ & $38.46 \pm 1.17$ & $46.48 \pm 0.57^{*}$ & $55.81 \pm 0.81^{* *}$ & $61.65 \pm 1.06^{* *}$ & $63.44 \pm 0.75^{* *}$ \\
\hline F2 & $16.65 \pm 1.04$ & $21.62 \pm 0.67$ & $30.94 \pm 0.63$ & $37.63 \pm 0.39$ & $44.74 \pm 0.86^{*}$ & $47.76 \pm 0.82^{*}$ \\
\hline F3 & $42.47 \pm 0.84^{*}$ & $51.62 \pm 1.21^{* *}$ & $59.74 \pm 0.75^{* *}$ & $63.18 \pm 0.54^{* * *}$ & $68.21 \pm 0.61^{* * *}$ & $70.16 \pm 0.69^{* * *}$ \\
\hline $\mathrm{F} 4$ & $35.31 \pm 0.92$ & $38.32 \pm 0.62^{*}$ & $55.27 \pm 0.43^{* *}$ & $61.65 \pm 0.49^{* * *}$ & $65.36 \pm 0.72^{* * *}$ & $68.14 \pm 0.55^{* * *}$ \\
\hline F5 & $41.96 \pm 0.54^{*}$ & $53.78 \pm 1.31^{* *}$ & $61.21 \pm 0.69^{* * *}$ & $65.23 \pm 0.71^{* * *}$ & $71.96 \pm 0.47^{* * *}$ & $73.12 \pm 0.48^{* * *}$ \\
\hline
\end{tabular}

All the values were expressed as mean \pm SEM. ${ }^{*} P<0.05,{ }^{* *} P<0.01$, and ${ }^{* * *} P<0.001$ when compared to control group (one-way ANOVA followed by Dunnett's: compare all versus control test).

TABLE 4: Hydrogen peroxide radical scavenging activity of flavone derivatives.

\begin{tabular}{|c|c|c|c|c|c|c|}
\hline & \multicolumn{6}{|c|}{ \% Scavenging activity $\left(\mathrm{H}_{2} \mathrm{O}_{2}\right)$} \\
\hline & $25 \mu \mathrm{g} / \mathrm{mL}$ & $50 \mu \mathrm{g} / \mathrm{mL}$ & $75 \mu \mathrm{g} / \mathrm{mL}$ & $100 \mu \mathrm{g} / \mathrm{mL}$ & $125 \mu \mathrm{g} / \mathrm{mL}$ & $150 \mu \mathrm{g} / \mathrm{mL}$ \\
\hline Ascorbic acid & $71.23 \pm 0.65$ & $76.57 \pm 0.49$ & $84.06 \pm 0.81$ & $88.19 \pm 0.56$ & $92.21 \pm 0.71$ & $96.63 \pm 0.63$ \\
\hline Tocopherol & $73.02 \pm 0.43$ & $76.26 \pm 0.66$ & $82.43 \pm 0.73$ & $90.38 \pm 0.87$ & $93.65 \pm 0.63$ & $95.47 \pm 0.48$ \\
\hline Rutin & $77.13 \pm 0.69$ & $82.15 \pm 0.87$ & $88.43 \pm 0.34$ & $92.35 \pm 0.61$ & $97.16 \pm 0.46$ & $98.84 \pm 0.74$ \\
\hline $\mathrm{F} 1$ & $28.21 \pm 0.84$ & $32.52 \pm 0.77$ & $38.33 \pm 0.87^{*}$ & $47.41 \pm 0.36^{* *}$ & $55.34 \pm 0.67^{* *}$ & $57.84 \pm 0.69^{* *}$ \\
\hline $\mathrm{F} 2$ & $13.75 \pm 0.60$ & $17.12 \pm 0.97$ & $25.77 \pm 0.68$ & $32.35 \pm 0.79$ & $36.47 \pm 0.68$ & $42.19 \pm 0.48^{*}$ \\
\hline F3 & $37.43 \pm 0.48$ & $48.35 \pm 0.91^{* *}$ & $53.19 \pm 0.57^{* *}$ & $56.78 \pm 0.45^{* * *}$ & $60.46 \pm 0.46^{* * *}$ & $63.16 \pm 0.84^{* * *}$ \\
\hline $\mathrm{F} 4$ & $31.62 \pm 0.54$ & $35.13 \pm 0.77$ & $46.91 \pm 0.74^{*}$ & $51.85 \pm 0.78^{* *}$ & $57.74 \pm 0.56^{* *}$ & $61.39 \pm 0.43^{* *}$ \\
\hline F5 & $43.07 \pm 0.48^{*}$ & $51.72 \pm 0.76^{* *}$ & $57.68 \pm 0.49^{* *}$ & $62.86 \pm 0.65^{* * *}$ & $70.21 \pm 0.71^{* * *}$ & $72.26 \pm 0.78^{* * *}$ \\
\hline
\end{tabular}

All the values were expressed as mean \pm SEM. ${ }^{*} P<0.05,{ }^{* *} P<0.01$, and ${ }^{* * *} P<0.001$ when compared to control group (one-way ANOVA followed by Dunnett's: compare all versus control test).

\section{Acknowledgment}

Authors are thankful to Department of Pharmacy, University of Malakand, Khyber Pakhtunkhwa, Pakistan, for provision of laboratory facilities.

\section{References}

[1] S. Iqbal, U. Younas, K. W. Chan, M. Zia-Ul-Haq, and M. Ismail, "Chemical composition of Artemisia annua L. leaves and antioxidant potential of extracts as a function of extraction solvents," Molecules, vol. 17, no. 5, pp. 6020-6032, 2012.

[2] Y. Christen, "Oxidative stress and Alzheimer disease," The American Journal of Clinical Nutrition, vol. 71, no. 2, pp. 621$629,2000$.

[3] A. Nunomura, R. J. Castellani, X. Zhu, P. I. Moreira, G. Perry, and M. A. Smith, "Involvement of oxidative stress in Alzheimer disease," Journal of Neuropathology and Experimental Neurology, vol. 65, no. 7, pp. 631-641, 2006.

[4] A. Wood-Kaczmar, S. Gandhi, and N. W. Wood, "Understanding the molecular causes of Parkinson's disease," Trends in Molecular Medicine, vol. 12, no. 11, pp. 521-528, 2006.

[5] G. Davì, A. Falco, and C. Patrono, "Lipid peroxidation in diabetes mellitus," Antioxidants and Redox Signaling, vol. 7, no. 1-2, pp. 256-268, 2005.

[6] D. Giugliano, A. Ceriello, and G. Paolisso, "Oxidative stress and diabetic vascular complications," Diabetes Care, vol. 19, no. 3, pp. 257-267, 1996.
[7] C. A. Hitchon and H. S. El-Gabalawy, "Oxidation in rheumatoid arthritis," Arthritis Research and Therapy, vol. 6, no. 6, pp. 265278, 2004.

[8] M. R. Cookson and P. J. Shaw, "Oxidative stress and motor neurone disease," Brain Pathology, vol. 9, no. 1, pp. 165-186, 1999.

[9] H. Sies, "Oxidative stress: oxidants and antioxidants," Experimental Physiology, vol. 82, no. 2, pp. 291-295, 1997.

[10] K. J. Davies, "Oxidative stress: the paradox of aerobic life," Biochemical Society Symposium, vol. 61, no. 2, pp. 1-31, 1995.

[11] S. G. Rhee, "Cell signaling. $\mathrm{H}_{2} \mathrm{O}_{2}$, a necessary evil for cell signaling," Science, vol. 312, no. 5782, pp. 1882-1883, 2006.

[12] C. G. Mohan, M. Deepak, G. L. Viswanatha et al., "Anti-oxidant and anti-inflammatory activity of leaf extracts and fractions of Mangifera indica," Asian Pacific Journal of Tropical Medicine, vol. 6, no. 4, pp. 311-314, 2013.

[13] C. R. Kim, S. J. Choi, S. S. Oh et al., "Rubus coreanus Miquel inhibits acetylcholinesterase activity and prevents cognitive impairment in a mouse model of dementia," Journal of Medicinal Food, vol. 16, no. 9, pp. 785-792, 2013.

[14] A. Braca, C. Sortino, M. Politi, I. Morelli, and J. Mendez, "Antioxidant activity of flavonoids from Licania licaniaeflora," Journal of Ethnopharmacology, vol. 79, no. 3, pp. 379-381, 2002.

[15] T. Ozawa, "Genetic and functional changes in mitochondria associated with aging," Physiological Reviews, vol. 77, no. 2, pp. 425-464, 1997.

[16] S. Ray, "A theoretical study of 1, 1-diphenyl-2-picrylhydrazyl (dpph) radical scavenging activities of flavonoids using electrotopological state atom (e-state) parameters," International 
Journal of Pharma and BioSciences, vol. 3, no. 3, pp. P543-P550, 2012.

[17] V. H. E. Susanti, S. Matsjeh, T. D. Mustofa Wahyuningsih, and T. Redjeki, "Synthesis, characterization and antioxidant activity of 7-hydroxy-3',4'-dimethoxyflavone," Indonesian Journal of Chemistry, vol. 12, no. 2, pp. 146-151, 2012.

[18] D. Kim, K. Ham, and S. Hong, "Synthetic approach to flavanones and flavones via ligand-free palladium(II)-catalyzed conjugate addition of arylboronic acids to chromones," Organic and Biomolecular Chemistry, vol. 10, no. 36, pp. 7305-7312, 2012.

[19] J. Zhao, Y. Zhao, and H. Fu, "Transition-metal-free intramolecular Ullmann-type O-arylation: synthesis of chromone derivatives," Angewandte Chemie International Edition, vol. 50, no. 16, pp. 3769-3773, 2011.

[20] R. A. Khan, M. R. Khan, S. Sahreen, and M. Ahmed, "Evaluation of phenolic contents and antioxidant activity of various solvent extracts of Sonchus asper (L.) Hill," Chemistry Central Journal, vol. 6, article 12, 2012.

[21] S. Sekhar, K. K. Sampath-Kumara, S. R. Niranjana, and H. S. Prakash, "In vitro antioxidant activity, lipoxygenase, cyclooxygenase-2 inhibition and dna protection properties of Memecylon species," International Journal of Pharmacy and Pharmaceutical Sciences, vol. 5, no. 2, pp. 257-262, 2013.

[22] M. Shoaib, I. Shah, N. Ali, and S. W. A. Shah, "In vitro acetylcholinesterase and butyrylcholinesterase inhibitory potentials of essential oil of Artemisia macrocephala," Bangladesh Journal of Pharmacology, vol. 10, no. 1, pp. 87-91, 2015.

[23] A. K. Tiwari, "Antioxidants: new-generation therapeutic base for treatment of polygenic disorders," Current Science, vol. 86, no. 8, pp. 1092-1102, 2004.

[24] S. Velavan, "Free radicals in health and diseases," Pharmacologyonline, vol. 1, no. 1, pp. 1062-1077, 2011.

[25] W. Lopaczynski and S. H. Zeisel, "Antioxidants, programmed cell death, and cancer," Nutrition Research, vol. 21, no. 1-2, pp. 295-307, 2001.

[26] M. J. Glade, "The role of reactive oxygen species in health and disease Northeast Regional Environmental Public Health Center University of Massachusetts, Amherst," Nutrition, vol. 19, no. 4, pp. 401-403, 2003.

[27] G. Poli, G. Leonarduzzi, F. Biasi, and E. Chiarpotto, "Oxidative stress and cell signalling," Current Medicinal Chemistry, vol. 11, no. 9, pp. 1163-1182, 2004.

[28] B. Halliwell, "Uric acid: an example of antioxidant evaluation," in Handbook of Antioxidants, E. Cadenas and L. Packer, Eds., Marcel Dekker, New York, NY, USA, 1996.

[29] G. Cioffi, M. D’Auria, A. Braca et al., "Antioxidant and freeradical scavenging activity of constituents of the leaves of Tachigalia paniculata," Journal of Natural Products, vol. 65, no. 11, pp. 1526-1529, 2002.

[30] F. Shahidi, "Antioxidants in food and food antioxidants," Die Nahrung, vol. 44, no. 3, pp. 158-163, 2000.

[31] N. C. Cook and S. Samman, "Flavonoids: chemistry, metabolism, cardioprotective effects, and dietary sources," The Journal of Nutritional Biochemistry, vol. 7, no. 2, pp. 66-76, 1996.

[32] M. Philip, "The use of the stable free radical diphenylpicrylhydrazy (DPPH) for estimating antioxidant activity," Songklanakarin Journal of Science and Technology, vol. 26, no. 2, pp. 211-219, 2003.

[33] W. Brand-Williams, M. E. Cuvelier, and C. Berset, "Use of a free radical method to evaluate antioxidant activity," LWT-Food Science and Technology, vol. 28, no. 1, pp. 25-30, 1995.
[34] S. Dudonné, X. Vitrac, P. Coutiére, M. Woillez, and J.-M. Mérillon, "Comparative study of antioxidant properties and total phenolic content of 30 plant extracts of industrial interest using DPPH, ABTS, FRAP, SOD, and ORAC assays," Journal of Agricultural and Food Chemistry, vol. 57, no. 5, pp. 1768-1774, 2009.

[35] J.-K. Moon and T. Shibamoto, "Antioxidant assays for plant and food components," Journal of Agricultural and Food Chemistry, vol. 57, no. 5, pp. 1655-1666, 2009.

[36] P. X. Nunes, S. F. Silva, R. J. Guedes, and S. Almeida, "Biological oxidations and antioxidant activity of natural products," in Phytochemicals as Nutraceuticals-Global Approaches to Their Role in Nutrition and Health, chapter 1, InTech, Rijeka, Croatia, 2012.

[37] D. Krishnaiah, R. Sarbatly, and R. Nithyanandam, "A review of the antioxidant potential of medicinal plant species," Food and Bioproducts Processing, vol. 89, no. 3, pp. 217-233, 2011.

[38] I. Gülçin, D. Berashvili, and A. Gepdiremen, "Antiradical and antioxidant activity of total anthocyanins from Perilla pankinensis decne," Journal of Ethnopharmacology, vol. 101, no. 1-3, pp. 287-293, 2005.

[39] S. Sumaira, R. K. Muhammad, and A. K. Rahmat, "Phenolic compounds and antioxidant activities of Rumex hastatus D. Don. leaves," Journal of Medicinal Plants Research, vol. 5, no. 13, pp. 2755-2765, 2011.

[40] L. Rackova, M. Oblozinsky, D. Kostalova, V. Kettmann, and L. Bezakova, "Free radical scavenging activity and lipoxygenase inhibition of Mahonia aquifolium extract and isoquinoline alkaloids," Journal of Inflammation, vol. 4, article no. 15, 2007.

[41] P. Trouillas, C.-A. Calliste, D.-P. Allais et al., "Antioxidant, antiinflammatory and antiproliferative properties of sixteen water plant extracts used in the Limousin countryside as herbal teas," Food Chemistry, vol. 80, no. 3, pp. 399-407, 2003.

[42] M. F. Mahomoodally, A. Gurib-Fakim, and A. H. Subratty, "Antimicrobial activities and phytochemical profiles of endemic medicinal plants of Mauritius," Pharmaceutical Biology, vol. 43, no. 3, pp. 237-242, 2005.

[43] C. Kanadaswami, L.-T. Lee, P.-P. H. Lee et al., "The antitumor activities of flavonoids," In Vivo, vol. 19, no. 5, pp. 895-910, 2005.

[44] J. J. Van Zanden, L. Geraets, H. M. Wortelboer, P. J. Van Bladeren, I. M. C. M. Rietjens, and N. H. P. Cnubben, "Structural requirements for the flavonoid-mediated modulation of glutathione S-transferase P1-1 and GS-X pump activity in MCF7 breast cancer cells," Biochemical Pharmacology, vol. 67, no. 8, pp. 1607-1617, 2004.

[45] F. A.-F. Ragab, N. A. M. El-Sayed, A. A. H. M. Eissa, and A. M. El Kerdawy, "Synthesis and anticonvulsant activity of certain substituted furochromone, benzofuran and flavone derivatives," Chemical and Pharmaceutical Bulletin, vol. 58, no. 9, pp. 11481156, 2010.

[46] M. Ajay, A.-U. H. Gilani, and M. R. Mustafa, "Effects of flavonoids on vascular smooth muscle of the isolated rat thoracic aorta," Life Sciences, vol. 74, no. 5, pp. 603-612, 2003.

[47] J. Higgs, C. Wasowski, L. M. Loscalzo, and M. Marder, "In vitro binding affinities of a series of flavonoids for m-opioid receptors. Antinociceptive effect of the synthetic flavonoid 3,3dibromoflavanone in mice," Neuropharmacology, vol. 72, pp. 919, 2013.

[48] J. E. N. Dolatabadi, A. Mokhtarzadeh, S. M. Ghareghoran, and G. Dehghan, "Synthesis, characterization and antioxidant property of Quercetin-Tb(III) complex," Advanced Pharmaceutical Bulletin, vol. 4, no. 2, pp. 101-104, 2014. 
[49] T. T. Dao, Y. S. Chi, J. Kim, H. P. Kim, S. Kim, and H. Park, "Synthesis and inhibitory activity against COX-2 catalyzed prostaglandin production of chrysin derivatives," Bioorganic and Medicinal Chemistry Letters, vol. 14, no. 5, pp. 1165-1167, 2004.

[50] E. Ognibene, P. Bovicelli, W. Adriani, L. Saso, and G. Laviola, "Behavioral effects of 6-bromoflavanone and 5-methoxy-6,8dibromoflavanone as anxiolytic compounds," Progress in NeuroPsychopharmacology and Biological Psychiatry, vol. 32, no. 1, pp. 128-134, 2008.

[51] H. Viola, M. Marder, C. Wolfman, C. Wasowski, J. H. Medina, and A. C. Paladini, "6-Bromo-3' -nitroflavone, a new high affinity benzodiazepine receptor agonist recognizes two populations of cerebral cortical binding sites," Bioorganic \& Medicinal Chemistry Letters, vol. 7, no. 3, pp. 373-378, 1997.

[52] M. G. L. Hertog, D. Kromhout, C. Aravanis et al., "Flavonoid intake and long-term risk of coronary heart disease and cancer in the seven countries study," Archives of Internal Medicine, vol. 155, no. 4, pp. 381-386, 1995.

[53] Y. Cai, Q. Luo, M. Sun, and H. Corke, "Antioxidant activity and phenolic compounds of 112 traditional Chinese medicinal plants associated with anticancer," Life Sciences, vol. 74, no. 17, pp. 2157-2184, 2004. 

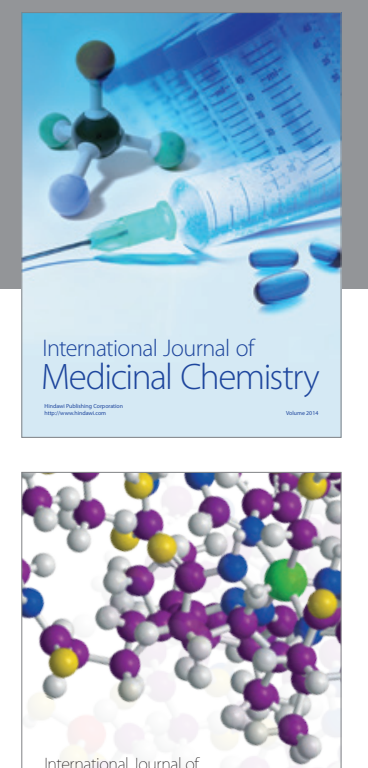

\section{Carbohydrate} Chemistry

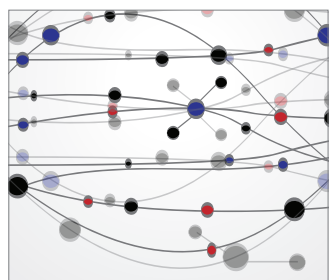

The Scientific World Journal
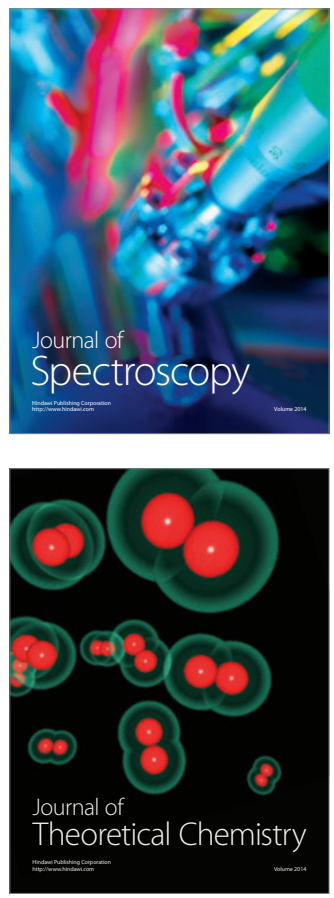
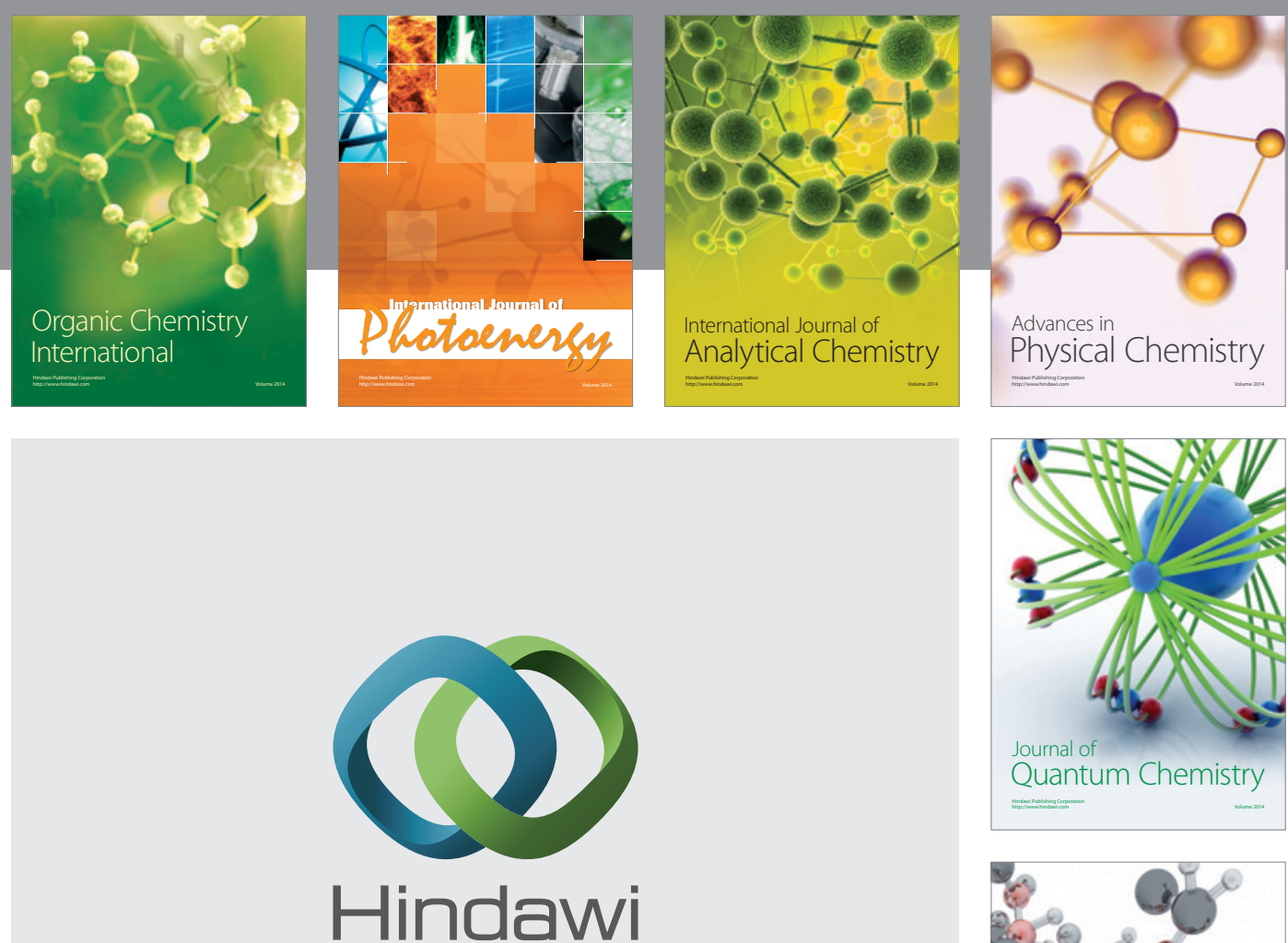

Submit your manuscripts at

http://www.hindawi.com

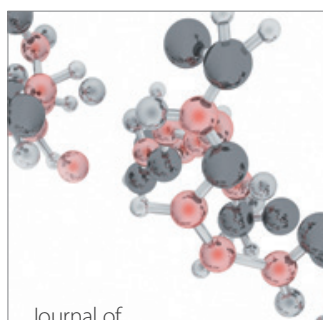

Analytical Methods

in Chemistry

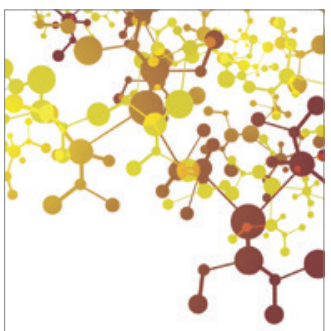

Journal of

Applied Chemistry

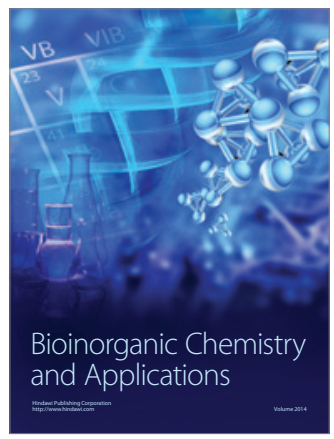

Inorganic Chemistry
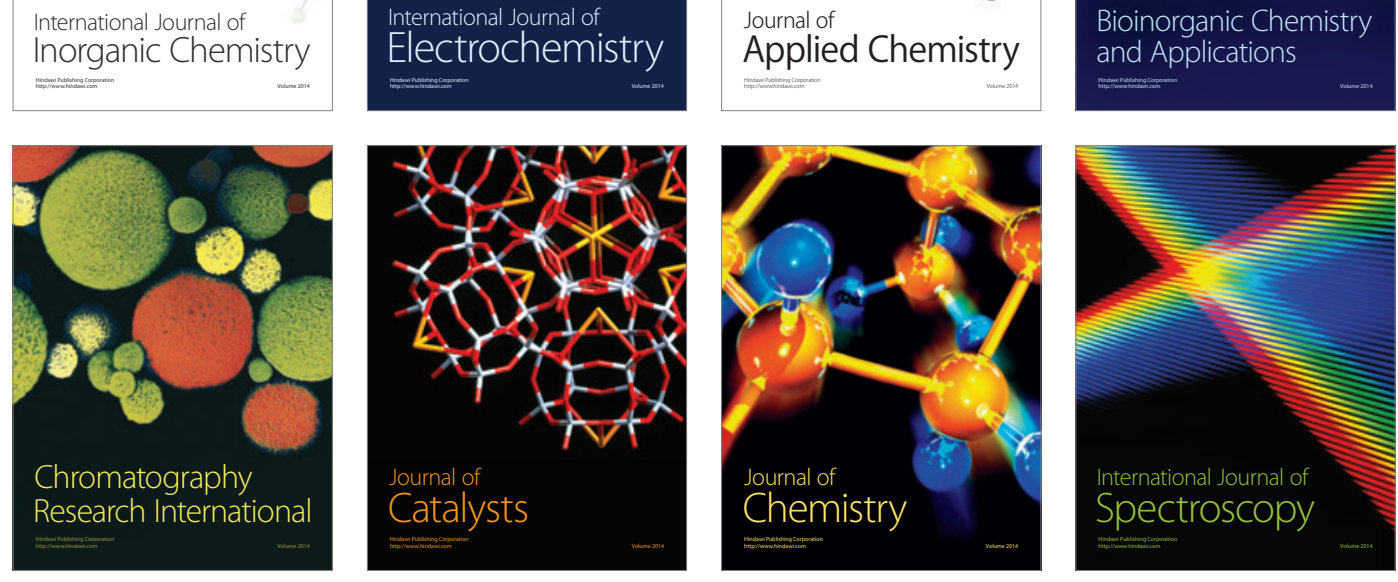